\title{
Geothermal System Study Case near Bucharest
}

\author{
Galina Prică ${ }^{1,}$, Lohengrin Onuțu ${ }^{2}$, and Grațiela Țârlea ${ }^{2 *}$ \\ ${ }^{1}$ The Romanian General Association of Refrigeration, Romania, 66 Blv. Pache Protopopescu,Bucharest, 021414, Romania \\ ${ }^{2}$ Technical University of Civil Engineering, Bucharest, Faculty of Building Systems, Romania, 66 Blv. Pache \\ Protopopescu,Bucharest, 021414, Romania
}

\begin{abstract}
The article shows a study case of a geothermal system near Bucharest. In the paper it is shown that for a good efficiency of a geothermal system for heating and air conditioning, it is important to follow a few steps. One step is a very accurate calculation of the heat and cold load. In the next step it is important to use a specific equipment to obtain the Thermal Response Test (TRT) of geological formations crossed by the borehole. TRT is helpful in providing information related to the evolution of the soil temperature while introducing a thermal load. All information that can be obtained or calculated from the TRT will provide how the climate system will function in time and its efficiency. Furthermore, the effective thermal conductivity and thermal resistance of the well will be determined, extremely important parameters in designing the correct length of the geoheat exchanger. The article used specific software to simulate the evolution of parameters in time, for soil and heat pump. Earth Energy Design offer information for the number of needed boreholes, the depth and the yearly evolution of the soil's temperature in time for the system etc. Following all these main steps, finally a very efficient system can be designed, that can ensure the heating and produce hot water for the consumption of a house, office building or of other destination buildings.
\end{abstract}

\section{Introduction}

Heat pumps are a friendly alternative, thus in the context of a growing concern about energy savings, it was a go to option for heritage buildings. Even it is used the correct insulation for the walls it is very difficult to find the best solution for heating and cooling the building. Thus, when the rehabilitation of the Minovici Museum's building commenced, the solution with geothermal heat pumps was taken into account . [1]

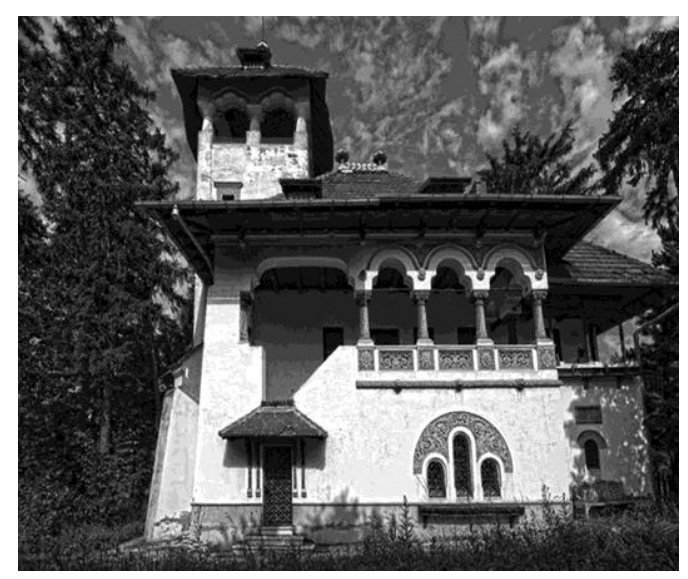

Fig. 1. Vila Minovici

The building in this study case is The Folk Art Museum "Prof. Dr. Nicolae Minovici ". Its architecture's charm is specific to the sub-Carpathian area of the Romanian Country.

It was built in 1905, under the plans of the architect Cristofi Cerchez and was designated from the beginning to be open to public even though it also served as a personal household. It has been open to the public since 1914.

The museum is located in Dr. Nicolae Minovici Street no. 1, near the Miorita Fountain, in the Băneasa neighborhood.

Because of the flowers that cover the building it is also known as the "Villa with the Bells".

\section{Steps of correct design of the system}

\subsection{Calculate the load}

The building is located in the $\mathrm{N}^{\text {th }}$ part of Bucharest, near the outskirts of the city. It is located between other buildings with maximum 3-4 levels, in an area with houses and old villas, so this is a windy area and with a cooler temperature in the winter and warmly in the summer.

The museum has, in fact 4 building but in this study case we refer only to the main building. The principal data of this building are:

$\mathrm{Ac}=236 \mathrm{~m}^{2}$.

Corresponding author: gratiela.tarlea@gmail.com 
$\mathrm{H}_{\text {total }}=18.40 \mathrm{~m}$, and takes place on 4 levels, namely: $\mathrm{S}$ (partial) $+\mathrm{P}+\mathrm{E}+\mathrm{M}$.

For a correct design we have to take into consideration all the data.

The foundations is a continuous type of concrete, and the structure is made of brick-built brick masonry that is not in a good condition.

The floors are made of wooden tiles at the first floor and the ceramic tiles for the ground floor and the roof are made with a ceramic tile cover.

Because the main exhibits of the museum are popular costumes and have considerable age, it is important to ensure optimal exposure conditions that require an accurate temperature and humidity, which obviously implies a very precisely calculation of the thermal loads: $30 \mathrm{~kW}$ th for heating and $29 \mathrm{kWth}$ for cooling;

\subsection{Response test}

The thermal response, test is a way to determine ground thermal properties that are very important for design the system with ground source heat pumps. The test concern in injecting a constant known heat power into a borehole of the geoheat exchanger and then measuring the temperature response. $[2,3]$

A good test provide the right undisturbed formation ground temperature and that permit calculate the thermal conductivity and the borehole thermal resistance and estimate of the thermal diffusivity.

These values, are indispensable for the optimal design of a geothermal system. All this values will be used in a geothermal design program to design for optimize the cost of the system. Earth Energy designer software for example can estimate the cost of the geoheat exchanger.

For the response test of this study case was use un American equipment named GeoCube and the results are:

Thermal Conductivity $\left(\mathrm{W} /\left(\mathrm{m}^{*} \mathrm{~K}\right)\right): 2.10$

Thermal Diffusivity (est.) ( $\mathrm{m}^{\wedge} 2 /$ day) $: 0.089$

Average Heat Flux (W/m) : 59.9

Thermal Resist (BTR) (m*K/W) : 0.13

Average Flow Rate (L/s) : 0.36

Test Duration (hr) : 72

Calculation Interval : 6.0 - 46.0 Hours

\section{Borehole Input Parameters}

Undisturbed Ground Temperature $\left({ }^{\circ} \mathrm{C}\right): 13.6$

Depth (m) : 70.0

Borehole Diameter (mm) : 140.0

Pipe Size: 1" (32x3mm)

Grout Thermal Conductivity $(\mathrm{W} /(\mathrm{m} * \mathrm{~K})): 1.70$

Drilling Method : Standard

Drilling Time (hr) : 5.0

Diffusivity Input Parameters

Soil/Rock Specific Heat - Dry $\left(\mathrm{kJ} /\left(\mathrm{K}^{*} \mathrm{~kg}\right)\right)$ : N/A

Soil/Rock Density - Dry $\left(\mathrm{kg} / \mathrm{m}^{\wedge} 3\right)$ : N/A

Moisture (0-100) (\%) : N/A

Flow Rate Input Parameters

TC Unit Model Name: GeoCube Standard

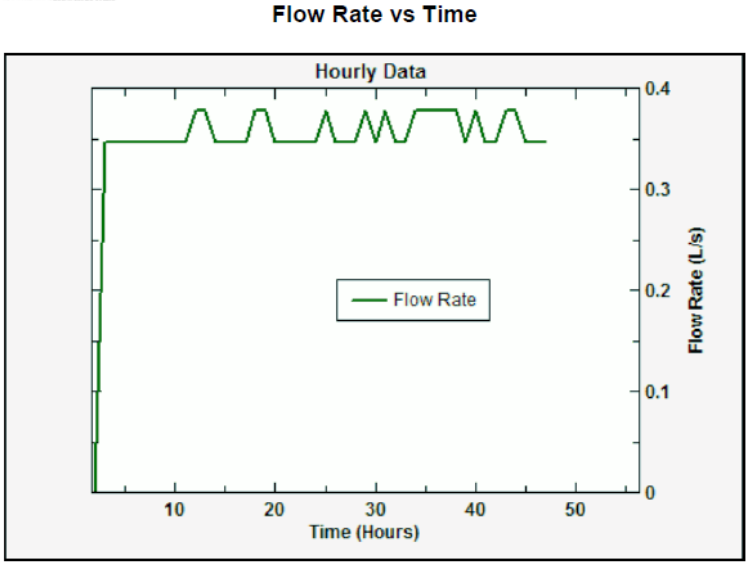

Fig. 2. Flow rate vs time

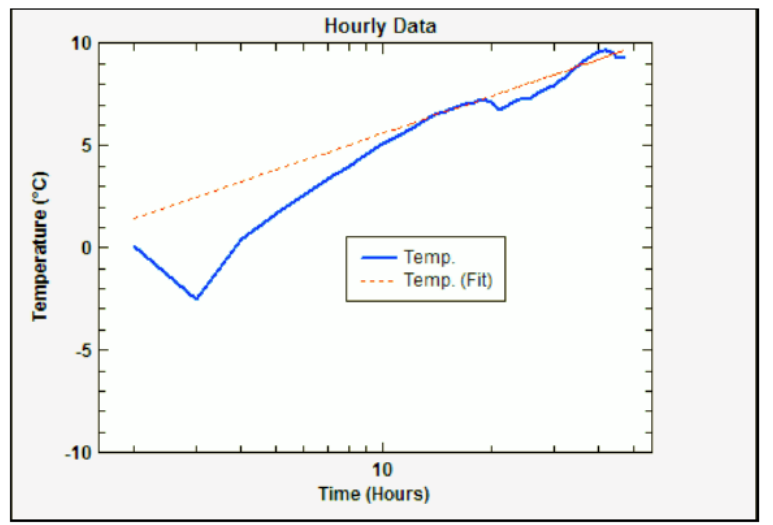

Fig. 3. Flow rate vs time

\subsection{The results of the response test}

From all the data, the most important parameter is thermal conductivity because is taken into account for the correct sizing of the GHE.

The expected value of thermal conductivity in this case was $2.08 \mathrm{~W} / \mathrm{m} * \mathrm{~K}$ and the value resulting from calculation is $2.10 \mathrm{~W} / \mathrm{m} * \mathrm{~K}$. Percentage means: less than $1 \%$. This is an insignificant difference.

Nor is thermal diffusivity much different than expected. The project was $0.094 \mathrm{~m}^{2} /$ day, and the thermal conductivity test resulted in $0.089 \mathrm{~m}^{2} /$ day. This means in percent: less than $6 \%$. This value also falls within the margin of error.

\subsection{Using specialized software}

Data from the Thermal Response test along with other calculated data is usually used in a specialized software to determine both the length of the heat exchanger and its time behaviour. Earth Energy Designer is one of that used especially in Europe. It's an easy-to-use software with a friendly interface. $[4,5]$

EED simulates the behaviour of the geothermal heat exchanger - GHE - over time, more precisely the evolution over time of the temperature of the rocks crossed by the exchanger. $[6,7]$ 
Table 1. Value of data for the borehole.

\begin{tabular}{|c|c|c|}
\hline Size & U.M & Values \\
\hline Borehole deep & $\mathrm{m}$ & 75 \\
\hline Distance between boreholes & $\mathrm{m}$ & 5 \\
\hline Borehole diameter & $\mathrm{mm}$ & 140 \\
\hline Pipe U diameter & $\mathrm{mm}$ & 32 \\
\hline $\begin{array}{c}\text { Thickness } \\
\text { of the U-pipe wall }\end{array}$ & $\mathrm{mm}$ & 3 \\
\hline $\begin{array}{c}\text { The thermal conductivity } \\
\text { of the U-pipe }\end{array}$ & $\mathrm{W} /(\mathrm{m} \mathrm{K})$ & 0.42 \\
\hline $\begin{array}{c}\text { The distance } \\
\text { between the pipe axes }\end{array}$ & $\mathrm{mm}$ & 108 \\
\hline $\begin{array}{c}\text { Thermal conductivity } \\
\text { of cement }\end{array}$ & $\mathrm{W} /(\mathrm{m} \mathrm{K})$ & 1.7 \\
\hline Pipe / fill contact resistance & $(\mathrm{m} \mathrm{K}) / \mathrm{W}$ & 0 \\
\hline
\end{tabular}

Table 2. Value of data for the carrier fluid - water.

\begin{tabular}{|c|c|c|}
\hline Size & U.M & Values \\
\hline $\begin{array}{c}\text { Thermal } \\
\text { conductivity }\end{array}$ & $\mathrm{W} /(\mathrm{m} \mathrm{K})$ & 0.59 \\
\hline Heat specific mass & $\mathrm{J} /(\mathrm{Kg} \mathrm{K})$ & 4186 \\
\hline Density & $\mathrm{Kg} / \mathrm{m}^{3}$ & 999.2 \\
\hline Viscozity & $\mathrm{Kg} /(\mathrm{m} \mathrm{s})$ & 0.0011 \\
\hline $\begin{array}{c}\text { The freezing point } \\
{ }^{\circ} \mathrm{C}\end{array}$ & 0 \\
\hline $\begin{array}{c}\text { Flow through the } \\
\text { well }\end{array}$ & $1 / \mathrm{s}$ & 0.19 \\
\hline
\end{tabular}

Table 3. The value of the basic parameters.

\begin{tabular}{|c|c|c|}
\hline Size & U.M & Values \\
\hline $\begin{array}{c}\text { Annual domestic } \\
\text { hot water demand }\end{array}$ & MWh & 8.26 \\
\hline Annual heating load & MWh & 63 \\
\hline $\begin{array}{c}\text { Annual cooling load } \\
\text { Factor (ACM) }\end{array}$ & MWh & 50 \\
\hline $\begin{array}{c}\text { Seasonal Performance } \\
\text { Feasonal Performance } \\
\text { Factor (FPS Heating) }\end{array}$ & - & 3.1 \\
\hline
\end{tabular}

\begin{tabular}{|c|c|c|}
\hline $\begin{array}{c}\text { Seasonal performance } \\
\text { factor (FPS cooling) }\end{array}$ & - & 6 \\
\hline
\end{tabular}

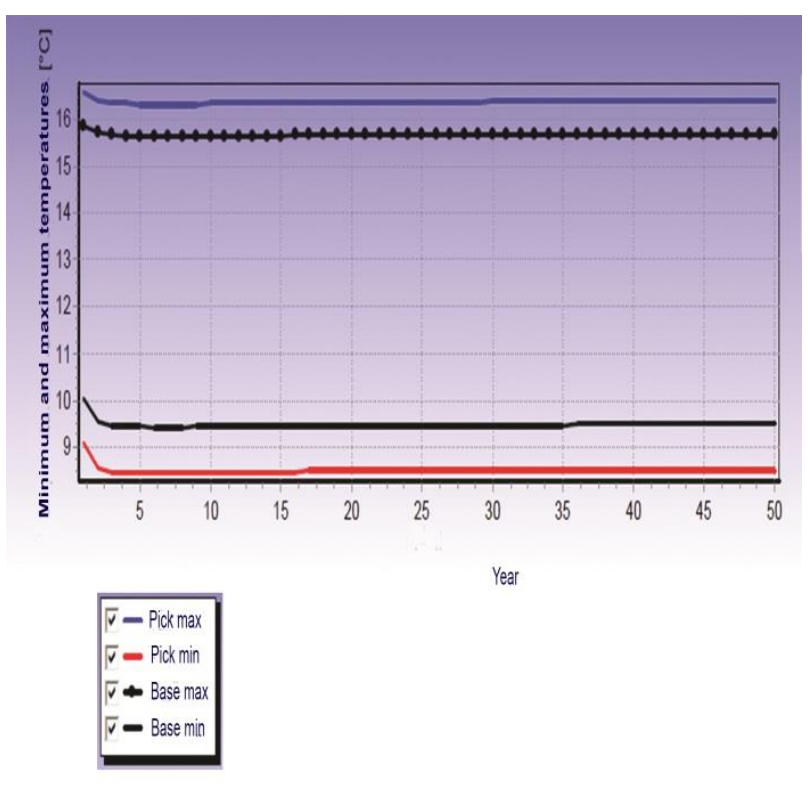

Fig. 4. The evolution of fluid temperature over the 50 years

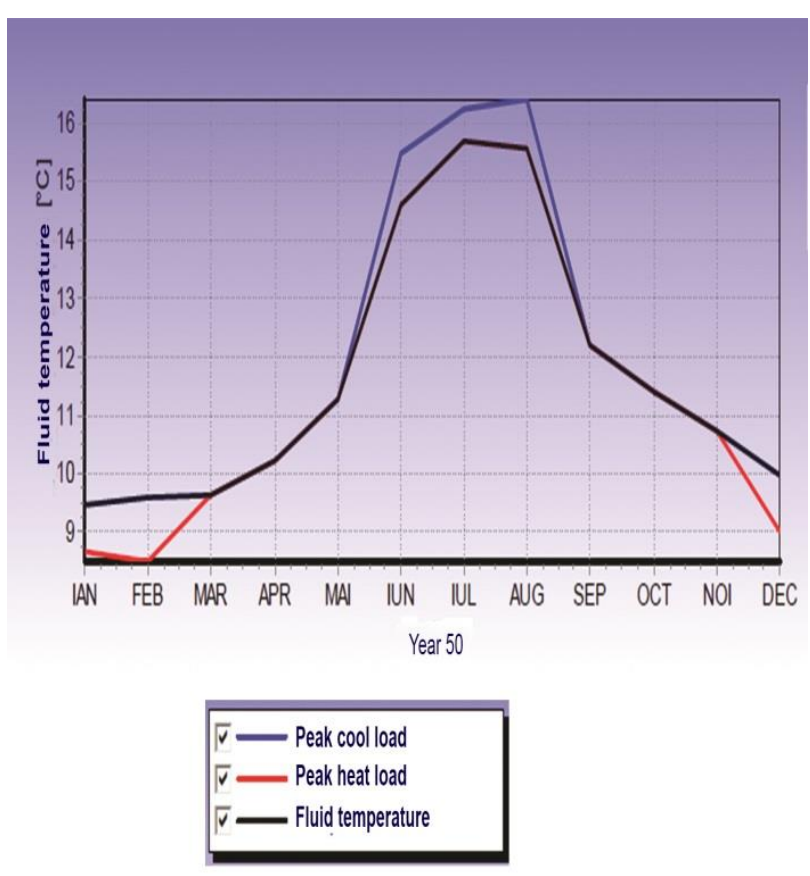

Fig. 5. The evolution of fluid temperature for the year 50

Number of boreholes: 32

Drilling depth : $75 \mathrm{~m}$

Total drilling length : $2400 \mathrm{~m}$ 


\section{Conclusions}

This paper presented a study case of a geothermal system near Bucharest for a museum building.

Calculating the heat requirement it is imperative for the simulation to be as close as possible to the real situation and in this work the error was under $6 \%$.

The use of specialized software EED facilitates a modeling work and offers a lot of very useful data for making an efficient geoheat exchanger for old buildings.

\section{References}

1. G. Prică, L. Onuțu, R. Moroianu, Indoor Climate System for Vila Minovici Museum Insured by Plants that Use Geothermal Sources, The $27^{\text {th }}$ International Conference - BSEE 2017, Building Services and Energy Efficiency, Romania Iasi (2017)

2. Implementing Performance of buildings Directive, pag 471- 489. Lisabona, (2016)

3. M. Ben International Energy Agency, Programme on Energy in Buildings and Communities, Total Energy Use in Buildings: Analysis and Evaluation Methods, Final report of Annex 53, (2014)

4. Prică, G, Vinceriuc, M, Țârlea, A - The Retrofit Of The HVAC System Using Geothermal Heat Pumps, Revista Termotehnica 2, (2010)

5. Prică, G, Vinceriuc, M, Țârlea, G, The retrofit of Heating and Cooling System of the Laboratory Using a Geoexchange Technology, 41 st International Congress \& Exhibition on Heating, Refrigeration and Air Conditioning, Belgrad, (2010)

6. Prică, G, Țârlea, G, Studiu experimental al performantelor energetice ale pompelor de căldură sol-apă, a 47 - cea Conferința națională de instalații pentru începutul mileniului trei - Creșterea performanței energetice a clădirilor și a intalaţiilor aferente, Sinaia (2012)

7. Prică, G, Teză de doctorat, Cercetări privind optimizarea pompelor de căldură care au solul drept sursă termică, Universitatea Tehnică de Construcții București, (2015) 